\title{
28 Research Square \\ Identification of a virulence tal gene in the cotton pathogen, Xanthomonas citri pv. malvacearum strain Xss-V2-18
}

\section{Fazal Haq}

Shanghai Jiao Tong University

\section{Shiwang Xie}

Shanghai Jiao Tong University

Kunxuan Huang

Shanghai Jiao Tong University

Syed Mashab Ali Shah

Shanghai Jiao Tong University

Wenxiu Ma

Shanghai Jiao Tong University

LuLu Cai

Shanghai Jiao Tong University

Xiameng Xu

Shanghai Jiao Tong University

Zhengyin $\mathrm{Xu}$

Shanghai Jiao Tong University

\section{Sai Wang}

Shanghai Jiao Tong University

Lifang Zou

Shanghai Jiao Tong University

Bo Zhu

Shanghai Jiao Tong University

Gongyou Chen ( $\sim$ gyouchen@sjtu.edu.cn)

Shanghai Jiao Tong University

\section{Research article}

Keywords: Bacterial blight of cotton, Xanthomonas citri pv. malvacearum, transcription-activator-like effector, virulence.

Posted Date: February 19th, 2020 
DOI: https://doi.org/10.21203/rs.2.20197/v2

License: (c) (1) This work is licensed under a Creative Commons Attribution 4.0 International License. Read Full License

Version of Record: A version of this preprint was published at BMC Microbiology on April 15th, 2020. See the published version at https://doi.org/10.1186/s12866-020-01783-x. 


\section{Abstract}

Background: Bacterial blight of cotton (BBC), which is caused by the bacterium Xanthomonas citri pv. malvacearum $(\mathrm{Xcm})$, is a destructive disease in cotton. Transcription activator-like effectors (TALEs), encoded by tal-genes, play critical roles in the pathogenesis of xanthomonads. Characterized strains of cotton pathogenic Xcm harbor 8-12 different tal genes and only one of them is functionally decoded. Further identification of novel tal genes in Xcm strains with virulence contributions are prerequisite to decipher the Xcm-cotton interactions. Results: In this study, we identified six tal genes in Xss-V2-18, a highly-virulent strain of Xcm from China, and assessed their role in BBC. RFLP-based Southern hybridization assays indicated that Xss-V2-18 harbors the six tal genes on a plasmid. The plasmidencoded tal genes were isolated by cloning BamHI fragments and screening clones by colony hybridization. The tal genes were sequenced by inserting a Tn5 transposon in the DNA encoding the central repeat region (CRR) of each tal gene. Xcm TALome evolutionary relationship based on TALEs CRR revealed relatedness of Xss-V2-18 to MSCT1 and MS14003 from the United States. However, Tal2 of XssV2-18 differs at two repeat variable diresidues (RVDs) from Tal6 and Tal26 in MSCT1 and MS14003, respectively, inferred functional dissimilarity. The suicide vector pKMS1 was then used to construct tal deletion mutants in Xcm Xss-V2-18. The mutants were evaluated for pathogenicity in cotton based on symptomology and growth in planta. Four mutants showed attenuated virulence and all contained mutations in tal2. One tal2 mutant designated M2 was further investigated in complementation assays. When tal2 was introduced into Xcm M2 and expressed in trans, the mutant was complemented for both symptoms and growth in planta, thus indicating that tal2 functions as a virulence factor in Xcm Xss-V218. Conclusions: Overall, the results demonstrated that Tal2 is a major pathogenicity factor in Xcm strain Xss-V2-18 that contributes significantly in BBC. This study provides a foundation for future efforts aimed at identifying susceptibility genes in cotton that are targeted by Tal2.

\section{Background}

Cotton (Gossypium spp.) is an economically-important crop worldwide and is a significant source of fiber, feed, oil and biofuel [1]. The primary cotton production areas are located in the southern United States (USA), Central America, western Africa, and central and eastern Asia. According to the 2017/18 world ranking, China leads the world in cotton production followed by India, the USA and Pakistan [2]. Gossypium spp. contains over 50 species, including G. arboreum, G. herbaceum, G. hirsutum and $G$. barbadense. G. arboretum and $G$. herbaceum are diploid $(2 n=26)$, whereas $G$. hirsutum and $G$. barbadense are tetraploid $(4 n=52)[3,4] . G$. hirsutum is the predominant species and produces with $90 \%$ of the world's cotton fiber production [5]. This species is impacted by a devastating bacterial disease known as bacterial blight of cotton (BBC), which is caused by Xanthomonas citri pv. malvacearum. The first detailed description of BBC was reported in the USA [6]. However, this disease currently occurs in all cotton production areas and causes significant yield losses (5-35\%) either by injury to the plant or direct damage to the boll [7]. 
$\mathrm{Xcm}$ is able to infects all above-ground parts of cotton at any developmental stage starting with seedlings [8]. Typical BBC symptoms include cotyledon/seedling blight, angular leaf spots, water-soaked lesions, black arm of petioles and stems, boll rot and boll shedding $[8,9]$. The main virulence factors that contribute to the pathogenicity and adaptation of bacterial pathogens include exopolysaccharides, lipopolysaccharides, adhesins, protein secretion systems, siderophores, quorum sensing, biofilms, chemotactic sensors and degradative enzymes [10-13]. Particularly, type III secreted effector (T3SE) proteins play an important role in bacterial pathogenicity [10-12,14] and have been identified in Xanthomonas spp. [14-20]. One of the most studied groups of T3SEs are the transcriptional-activator like (tal) effector (TALE) proteins [21-28].

TALE proteins, functionally resemble eukaryotic transcription factors, are localized to the host plant nucleus where they bind to specific promoter sequences known as effector-binding elements (EBEs), thus regulating host gene expression [29-31]. TALEs belong to the avrBs3/pthA gene family [26], which is highly conserved among different Xanthomonas spp. TALEs contain an N-terminal T3S signal domain, a central repeat region (CRR), C-terminal nuclear localization signals (NLS), and an acid activation domain (AD) $[30,31]$. CRRs contain tandem repeats of 33-35 amino acids that differ only at residues 12 and 13; these are designated repeat variable di-residues (RVDs) and determine the specificity of DNA binding [3032]. TALE-mediated activation of EBEs can induce host susceptibility $(S)$ or resistance $(R)$ genes $[29,30]$. For example, the TALEs PthXo1 and PthXo2 from X. oryzae pv. oryzae (Xoo) were shown to enhance the expression of rice genes OSSWEET11 and OSSWEET13, which are required for susceptibility to bacterial leaf blight $[33,34]$. However, rice cultivars were resistant to Xoo when they contained OsSWEET11 and OsSWEET13 alleles lacking PthXo1 and PthXo2 EBEs [35-37]. Recently, a new rice S gene (OsERF\#123) was shown to be targeted by TalB in African strains of Xoo [38]. Other examples of TALEs include AvrBs3 that targets the pepper resistance gene Bs3 and AvrXa10, AvrXa23 and AvrXa27 that interact with rice $R$ genes Xa10, Xa23 and Xa27, respectively [29, 39-41]. Recently, Cai et al. [21] reported that Tal7 from Xoo binds and activates the expression of the rice gene 0 s09g29100, an interaction that suppresses avrXa7$X a 7$ mediated resistance in rice. A number of truncated TALEs (truncTALEs) and interfering TALEs (iTALEs) have also been reported in Xoo that function as suppressors of Xa1-mediated defense in rice $[42,43]$.

Resistance to $\mathrm{Xcm}$ has been identified primarily in G. hirsutum. The genetic nature of resistance to BBC was first revealed in 1939, and efforts to breed cotton plants for resistance ensued shortly thereafter [44]. About 20 major $R$ genes or polygene complexes ( $B$ genes) participate in resistance to BBC in cotton $[7,8]$. Based on their virulence phenotype in differential cotton hosts, $X c m$ strains have been classified into 22 races that are named 1-22 [7]. Race 18 is the most common variant and was first isolated in 1973 [45, 46]. In some cases, the outcome of interactions between $X \mathrm{~cm}$ strains and differential cotton varieties is dependent on the avrBs3/pthA gene family in $\mathrm{Xcm}$, which indicates that $\mathrm{Xcm}$-cotton interactions follow the gene-for-gene model for host plant resistance $[7,10,47,48]$.

The number and diversity of tal effector genes varies among different species, pathovars and strains of Xanthomonas. For example, Xoo strains harbor 8-26 TALEs [49-53], Xoc strains contain 19-28 [49, 54, 55], 
$X t t$ strains contains 5-12 [56], Xtu strains contains 7-8 [56-58] and $X c m$ strains harbor 8-12 genes encoding tal effectors $[27,46,59]$. Some Xanthomonas spp. lack tal effector genes, such as $X$. citri pv. raphani strain 756C [54]. To date, at least 20 TALEs have been cloned and characterized from $X \mathrm{~cm}$ strains $[25,26,28,48]$. Among these, Avrb6 was the first Xcm TALE shown to be important for virulence [25]. Cox et al. [27] demonstrated that Avrb6 induced the expression of the cotton S gene, GhSWEET10, thus enhancing bacterial virulence and adaptation to the host.

The aim of the current study is to identify a novel virulent tal-gene encoding TALE protein in a highly virulent cotton pathogen, $\mathrm{Xcm}$ strain $\mathrm{Xss}_{\mathrm{S}} \mathrm{V}_{2}-18$ (from China).

\section{Results}

\section{TALEs of $\mathrm{Xss}_{\mathrm{S}} \mathrm{V}_{\mathbf{2}}-18$}

Restriction fragment length polymorphism (RFLP) analysis was conducted to estimate the number and size of $t a /$ genes in $X c m$ Xss $-V_{2}-18$. Since most tal genes retain two BamHI sites, $X c m$ Xss- $V_{2}-18$ plasmid and genomic DNAs were digested with $\mathrm{BamHI}$ and analyzed by Southern blotting as described above. Six bands hybridized to the probe in BamHI-digested genomic and plasmid DNA, indicating that $\mathrm{Xss}_{\mathrm{s}} \mathrm{V}_{2}-18$ contained six plasmid-encoded tal genes (Fig. 1A).

The six talgenes were cloned in pBluescript as BamHI fragments, giving rise to $\mathrm{pB}-t a / 1, \mathrm{pB}-\mathrm{tal} 2 \mathrm{pB}-\mathrm{ta} / 3$, pB-tal4, pB-tal5 and pB-tal6 (Fig. 1B) and confirmed by colony hybridization and sequence analysis. To obtain the complete DNA sequence of each tal gene, we inserted the Tn 5 transposon into the CRR region and used primer sets tal-F/RP and FP/tal-R to obtain the sequences (Fig. 1C). The tal gene sequences have been deposited in GenBank under the following accession numbers: MK654746 (ta/1), MK654747 (ta/2), MK654748 (ta/3), MK654749 (tal4), MK654750 (tal5) and MK654751 (tal6). Each tal gene encodes various numbers of RVDs, which are tandemly arranged and encoded within 102-bp direct repeats. There were 27.5, 102-bp repeat units in tal1, 25.5 in tal2, 21.5 in tal3, 18.5 in tal4, 15.5 in tal5 and 13.5 in tal6 (Fig. 2A).

To better understand the features of $X_{s s-} V_{2}-18$ TALEs, we compared them with TALEs in $X c m$ strains MSCT1, H1005, N1003, MS14003 and AR81009 [27, 46, 59]. Phylogenetic tree of TALEs from XCm strains were constructed by aligning TALE-CRR with DisTAL v1.1. All 53 TALEs (Xss-V $\mathrm{V}_{2}-18=6, M S C T 1=8$, $\mathrm{H} 1005=12, \mathrm{~N} 1003=9, \mathrm{MS14003}=8$ and AR81009=12) were classified into 6 major groups and 33 subgroups. Tal2 of Xss-V $2-18$, TAL6 of MCST and Tal26 of MS14003 fall in same group (Fig. 2B).

Nearly identical RVD sequences were observed for the six TALEs in Xss- $\mathrm{V}_{2}-18, \mathrm{MSCT} 1, \mathrm{H} 1005, \mathrm{MS} 14003$ and AR81009 (Fig. 2A). Differences of two RVDs between Tal2 of Xss-V2-18 and TAL6 of MSCT1, Tal26 of MS14003 indicate that they are functionally different from each other and may target a different EBE. The predicted theoretical EBE box for Tal2, Tal6 and Tal26 of Xss-V ${ }_{2}-18$, MSCT1 and MS14003, 
respectively, are mentioned in Figure S1. RVDs in Xcm strains included NI, NG, NS, HD and NN; the latter RVD was absent in Tal1, Tal2, Tal3 and Tal4.

\section{Xss- $\mathrm{V}_{2}-18$ tal deletion mutants}

To assess the role of $t a /$ genes in the virulence of $X s s-V_{2}-18$, we generated tal deletion mutants by homologous recombination using the suicide vector pKMS1 [60]. Fragments $a$ (580 bp) and $b$ (350 bp) were amplified on the left and right sides of DNA encoding the CRR, respectively, and cloned as a fused fragment in pKMSA1 (Fig. 3A, B). Construct pKMSA1 was introduced into $X c m$ Xss- $V_{2}-18$; after homologous recombination, 41 putative mutants were selected for PCR amplification using primers pKMSA1-5F/pKMSA1-3R (Table S1). Four putative mutants designated M1, M2, M3 and M4 contained a 930-bp PCR product, which is consistent with the size of the insert in pKMSA1 (Table 1, Fig. 3C). Southern hybridization indicated that one or more tal genes were deleted in the four mutants (Fig. 3D). M1 and M2 were lacking ta/3 and ta/2, respectively, M3 was missing tal2 and tal4, and M4 lacked tal2, tal4, tal5, and tal6. These results indicated that four tal loci underwent homologous exchange via pKMSA1, and copies of the plasmid pKMSA1 functioned to delete multiple tal genes simultaneously in M3 and M4.

A second round of deletion mutagenesis was conducted with plasmid PKMSA2, which contains a fusion of fragments $c(150 \mathrm{bp})$ and $d(300 \mathrm{bp})$ on the left and right sides of the DNA encoding the CRR, respectively (Fig. 3A). Construct pKMSA2 was used to generate new deletions in the M4 mutant, and potential new mutants were analyzed by PCR with primer pairs pKMSA2-5F/pKMSA2-3R (Table S1). Two mutants designated M5 and M6 contained a 450-bp PCR product that is consistent with the size of the insert in pKMSA2 (Fig. 3E). In addition to tal2, ta/4, tal5, and tal6, Southern hybridization indicated that mutant M5 contained a deletion in tal3. M6 was lacking both tal1 and tal3 (Fig. 3F); thus, M6 lacked all six tal genes and can be considered a talfree mutant of $\mathrm{Xss}_{\mathrm{V}} \mathrm{V}_{2}-18$.

\section{Virulence assays}

Xss- $\mathrm{V}_{2}-18$ and mutants M1-M6 were inoculated into cotton leaves and phenotypes were observed 3-5 days post-inoculation (Fig. $4 \mathrm{~A}$ ). $\mathrm{Xss}_{\mathrm{V}} \mathrm{V}_{2}-18, \mathrm{M} 1$, and $\mathrm{M} 4$ produced substantial water-soaked lesions in the inoculation sites; however, water-soaking was reduced in leaves inoculated with M2, M3, and M5 (Fig. 4A). In contrast, the region inoculated with the talfree mutant M6 showed cell death and necrosis (Fig. 4A) signifying that the loss of tal genes affect the virulence of $X s s-V_{2}-18$. On the second day postinoculation, the populations of the $M 2$ and $M 6$ mutants were significantly lower than $X s s-V_{2}-18, M 1, M 3$, M4 and M5 (Fig. 4B). On days 4 and 6 post-inoculation, the growth of $X s s-V_{2}-18$ was significantly higher than mutants M1-M6 with no significant difference among the mutants. These results indicated that some of the talgenes are involved in $\mathrm{Xss}-\mathrm{V}_{2}-18$ virulence, and the absence of selected tal genes impacted growth of the pathogen in planta.

Mutant M2, which lacks tal2, exhibited reduced symptomology and bacterial growth when compared to wild-type $\mathrm{Xss}_{\mathrm{s}} \mathrm{V}_{2}-18$ (Fig. 4A, B). Based on these observations, we speculated that tal2 might be involved 
in virulence; this was addressed by constructing pHZW-tal2 (Table 1) for complementation analysis. The $\mathrm{pHZW}$-tal2 construct was introduced into $\mathrm{Xcm} \mathrm{M} 2$, and the empty vector (ev, pHM1) was used as a negative control. Western blot analysis indicated that the Tal2 protein was produced in Xcm M2 (Fig. 4C). The wild-type $X s s-V_{2}-18$, mutant M2, M2(ev), and M2(tal2) were inoculated into cotton leaves; phenotypes were observed at 5-7 days post-inoculation (Fig. 4D), and bacterial growth was measured at $0,2,4$, and 6 days post-inoculation (Fig. 4E). Both water-soaking and bacterial growth in planta were restored to wild-type levels in Xcm M2 containing pHZW-ta/2 (Fig. 4D, E). Based on results shown in Fig. 4 , we conclude that Tal2 is major virulence factor in $\mathrm{Xss}_{\mathrm{V}} \mathrm{V}_{2}-18$.

\section{Discussion}

Until recently, BBC has been effectively controlled using classical $R$ genes [61-63]; however, in 2011 the disease re-emerged with a vengeance [46]. A known virulence factors, transcription activator-like effectors (TALEs), in $X \mathrm{~cm}$ are important for BBC. In previous studies, 8-12 tal genes were reported in $X \mathrm{~cm}$ [26-28, 48, 59]. Some $X c m$ tal genes, notably avrB101, avrB102 and $a v r B I n$, are known to cause an hypersensitive response (HR) on cotton [28], whereas avrb6 elicits water-soaking [48]. In this study, RFLP-based Southern hybridizations indicated that the highly-virulent $X c m$ strain $X s s-V_{2}-18$, which was originally isolated from Hainan, China, harbors six plasmid-borne tal genes (Fig. 1). In the genus Xanthomonas, the location and number of tal genes varies among species, pathovars and strains $[55,64]$. For example, strains of $X$. oryzae pv. oryzicola (Xoc) encode over 250 chromosomally-borne tal genes [55]; however, plasmidencoded tal genes are common in other Xanthomonas spp. Examples include the tal genes in $X$. citri pv. citri, $X$. citri pv. aurantifolii and $X$. axonopodis pv. manihotis, which were identified on plasmids pXAC66, pXcB and pXam46, respectively [65-67]. Feyter and Gabriel [28] and Showmaker et al. [59] reported the existence of plasmid-borne tal genes in $\mathrm{Xcm}$ strains $\mathrm{XcmH}$ and MSCT1, respectively. A draft genome sequence of the Xanthomonas trans/ucens pv. cerealis strain CFBP 2541 also indicate a plasmid borne tal-gene [68].

The presence of highly repetitive sequences in tal genes complicates efforts to obtain their nucleotide sequence; therefore, we used a Tn 5 insertion method as a sequencing strategy. This sequencing strategy for tal-genes was also used by others previously $[21,69]$. Normally the number of repeats in tal genes varies between 1.5 and 33.5, and each repeat encodes 33-34 amino acids that vary only at positions 12 and 13 (RVDs) [30]. In Xcm Xss- $\mathrm{V}_{2}-18$, we identified 27.5, 25.5, 21.5, 18.5, 15.5 and 13.5 tandemly arranged 102-bp direct repeats (encoding 34 amino acids) in tal1, tal2, tal3, tal4, tal5 and tal6, respectively. In order to understand how $X \mathrm{~cm}$ TALome differ from each other within and between strains, DisTAL and AnnoTALE were used to characterized $[50,70]$. $X \mathrm{~cm}$ encodes very diverse TAL effectors that were classified exclusively into 6 major groups and 33 sub-groups. TALE phylogenetic tree of $X \mathrm{~cm}$ strains showed that Tal2 of Xss-V $\mathrm{V}_{2}-18$, TAL6 of MCST and Tal26 (M26) of MS14003 fall in same group. Furthermore, RVDs based analysis showed that the six TALEs in Xss- $\mathrm{V}_{2}-18$ were identical or nearly identical to plasmid-borne TALEs in Xcm MSCT1, MS14003, H1005 and AR81009 which suggests that these genes may have been horizontally transferred $[65,71,72]$. The number and location of ta/ genes 
varied in the six $X c m$ strains; MSCT1 possess eight (seven plasmid-borne) [59], XcmH1005 has 12 (six plasmid- and six chromosomally-encoded) [27], XcmN1003 has nine (four plasmid-encoded) [27], MS14003 has 8 (7 plasmid-encoded) [46], AR81009 has 12 (six plasmid-encode) [46] and Xss- $\mathrm{V}_{2}-18$ has six plasmid-encoded talgenes (Fig. 1,2). The variation in number, location and RVD sequence in $X c m$ TALEs could be important for maintaining virulence in cotton cultivars grown in different geographical regions.

To assess the role of $t a l$ genes in $X s s-V_{2}-18$, we generated deletions in $X s s-V_{2}-18$ by homologous recombination with pKMS1 [60], which was previously used to generate deletion mutants in the rice pathogen, Xoc [73-75]. This is the first report where pKMS1 was used to generate ta/ deletion mutants in $\mathrm{Xcm}$, and the basic strategy was to replace the CRR (encoded by 102-bp repeat units) with up-and downstream fragments flanking the tal genes. Using construct pKMSA1, we obtained four mutants; M1 and M2 lacked tal3 and tal2, M3 had deletions in tal2 and tal4, and M4 lacked tal2, tal4, tal5 and tal6. We speculate that tal5 and tal6 might be located in the same gene cluster. The second knockout was obtained using pKMSA2 where up- and downstream flanking fragments (homology arms) were located closer to the CRR. Mutant M4 was used as a parental strain for the deletions generated with pKMSA2, and we recovered two new mutants designated M5 and M6. In addition to ta/2, tal4, tal5 and tal6, mutant M5 also lacks tal3, whereas M6 contains deletions in all six tal genes (Fig. 3). The symptoms induced by $M 2, M 3, M 5$ and M6 were significantly reduced relative to the wild-type, thus indicating that one or more tal genes contribute to symptom development in $\mathrm{Xss}_{\mathrm{s}} \mathrm{V}_{2}-18$. Mutants $\mathrm{M} 2, \mathrm{M} 3, \mathrm{M} 5$ and $\mathrm{M} 6$ all lack the tal2 gene; thus the potential contribution of tal2 to symptom development was further investigated.

Expression of tal2 in trans restored symptoms and growth in planta to the M2 mutant, thus confirming that Tal2 is a virulence factor (Fig. 4). Although the TALE repertoire of $X c m X_{s s}-V_{2}-18, M S C T 1, M S 14003$, $\mathrm{H} 1005$ and AR81009 is somewhat identical, Tal2 of Xss- $\mathrm{V}_{2}-18$ differs at two repeat variable diresidues (RVDs) from Tal6 in MSCT1 and Tal26 in MS14003, inferred functional dissimilarity.

TALEs functionally resemble eukaryotic transcription factors that target and regulate the expression of host genes by binding to their promoter sequences. TALE-triggered susceptibility has been well-studied, and the contribution of TALEs to virulence has been evaluated in many Xanthomonas spp. [21-23, 27, 57, 76-79]. For example, the TALEs PthXo1 and PthXo2 from Xoo were shown to enhance the expression of rice genes OSSWEET11 and OSSWEET13, which are required for susceptibility to bacterial leaf blight in rice $[33,34]$. However, rice cultivars were resistant to Xoo when they contained OSSWEET11 and OsSWEET13 alleles lacking PthXo1 and PthXo2 EBEs [35-37]. A recent study by Peng et al. [80] reported that Tal8 from Xtu target and induce the expression of host gene Ta-NCED-5BS, encode enzyme required for rate-limiting step in ABA biosynthesis, to promote disease susceptibility. In another new study, Wu et al. [81] shown that TAL-effector Brg11 from Ralstonia solanacearum enhance the expression of 5truncated $A D C$ (arginine decarboxylase) transcripts that subvert translational control and thereby inhibit competing pathogens. In $X c m$, Avrb6 was the first TALE shown to be important for virulence [25]. Recently, the $X \mathrm{Cm}$ effector Avrb6 was shown to target and induce the expression of the cotton $S$ gene, GhSWEET10, thus enhancing virulence and promoting disease [27]. The present study provides an 
important foundation for identifying potential $S$ genes that interact with Tal2, which will ultimately help us develop better control strategies for BBC.

\section{Conclusions}

In this study, we identified genes encoding TALEs in the highly-virulent $X c m$ strain, $X s s-V_{2}-18$ (from China), and assessed TALE roles in BBC. We found that $X s s-V_{2}-18$ encodes six plasmid-borne tal genes. Knockout mutagenesis of $X_{s s}-V_{2}-18$ tal genes and complementation analysis demonstrated that Tal2 is required for full virulence of $X s s-V_{2}-18$ on cotton. The identification of the Tal2 target in cotton will ultimately provide new avenues for developing BBC-resistant varieties.

\section{Methods}

\section{Bacterial strains, growth conditions, and plasmids}

The bacterial strains and plasmids used in this study are listed in Table 1. Escherichia coli strains were grown in Luria-Bertani (LB) medium ( $5 \mathrm{~g}$ yeast extract, $10 \mathrm{~g} \mathrm{NaCl}, 10 \mathrm{~g}$ tryptone/L) or LB with agar at $37^{\circ} \mathrm{C}$. $X \mathrm{~cm}$ strains were grown in nutrient broth (NB) $(1 \mathrm{~g}$ yeast extract, $3 \mathrm{~g}$ beef extract, $5 \mathrm{~g}$ polypeptone and 10 $\mathrm{g}$ sucrose/L) or NB with agar at $28^{\circ} \mathrm{C} . \mathrm{Xcm}$ transformants containing the first crossover event were grown on NAN (nutrient agar without sucrose) or NBN (NAN without agar) medium. For the second crossover event, transformants were plated on NAS agar (NAN with 10\% sucrose) [60]. When appropriate, antibiotics were added at the following concentrations $(\mu \mathrm{g} / \mathrm{mL})$ : ampicillin, 100; kanamycin, 20; spectinomycin, 25; and rifampicin, 50. The $\mathrm{pH}$ of both solid and liquid media was adjusted to 7.0-7.2.

\section{DNA preparation}

Total genomic DNA of Xss- $\mathrm{V}_{2}-18$ was isolated using the Bacterial Genomic DNA Extraction Kit (TaKaRa, China). The isolated gDNA pellet was re-suspended in double-distilled water. Bacterial plasmid DNA was isolated using the Plasmid Miniprep Kit (Omega, USA). The quality and quantity of genomic DNA and plasmid DNA were checked with NanoDrop spectrophotometer (Eppendorf). Routine plasmids isolation from E. coli was carried out by using the plasmid DNA Mini Kit (GBS Biotechnology, China).

\section{Isolating, cloning and sequencing of $X s s-\mathrm{V}_{2}-18$ tal genes}

The isolation and cloning of tal genes from $\mathrm{Xcm}$ strain $\mathrm{Xcc}_{\mathrm{cc}} \mathrm{V}_{2}-18$ followed a previously described procedure $[21,69,77,82]$ with minor modifications. Plasmid DNA and genomic DNA (50 $\mu \mathrm{g})$ were isolated from $X c m$, digested with $B a m H I$, and separated on $1.2 \%$ agarose gels. Specific ta/DNA fragments were then gel-purified and ligated into pBluescriptII SK(-) that was digested with BamHI and treated with calf intestinal phosphatase (CIP). The ligated products were introduced into competent $E$. coli cells by the heat shock method according to the manufacturer's protocol (Bio-Rad, USA). The successful cloning of tal genes in pBluescript II was validated by restriction digestion, colony hybridization and sequence analysis. 
The repeat units in tal genes complicate abilities to sequence the genes using conventional approaches. Thus, after cloning into pBluescript II SK(-), we used the EZ-Tn5 ${ }^{\mathrm{TM}}<\mathrm{KAN}-2>\operatorname{Tnp}$ Transposome ${ }^{\mathrm{TM}}$ Kit to insert Tn 5 into each tal gene as recommended by the manufacturer (Epicentre, Madison, WI). Clones with Tn 5 insertions in the middle of the repeat region were selected by Sphl digestion and sequenced using primers pair tal-F/RP and FP/tal-R (Table S1).

\section{TALEs phylogenetic tree construction and RVDs comparison}

For TALEs phylogeny, available genome sequences of $X c m$ strains MSCT1, H1005, N1003, MS14003 and AR81009 were obtained from the NCBI. TALE genes were predicted and analyzed in each genome using AnnoTALE v1.4.1 [50]. DisTAL v1.1 were used to align and classify TALEs based on their central repeat region [70].

For the TALE RVDs analysis, we used AnnoTALE version 1.4.1. The TALEs are grouped into classes based on the RVDs that shows possible functional and evolutionary relationship [50, 83].

\section{Construction of $\mathrm{Xss}-\mathrm{V}_{2}-18$ tal deletion mutants}

The $\mathrm{tal}$ genes in $\mathrm{Xcm}$ Xss- $\mathrm{V}_{2}-18$ were deleted by homologous recombination using the suicide vector pKMS1 [60]. The 5'and 3'fragments that flank the CRR repeat in tal genes are conserved [64] and were used as sites for homologous recombination. The left- and right-flanking fragments of each talgene were PCR-amplified using genomic DNA of Xcc strain Xcc049 (Table 1) as the template, and ligated into the MCS of pKMS1 [4], resulting in constructs pKMSA1 and pKMSA2, respectively. The new constructs were verified by restriction digestion and sequence analysis (TaKaRa, China). Constructs pKMSA1 and pKMSA2 were introduced into $X c m$ strain $X s s-V_{2}-18$ by electroporation; cells were then plated on NAN medium supplemented with kanamycin and incubated at $28^{\circ} \mathrm{C}$ for 4 days. Single colonies were then cultured in NBN broth at $28^{\circ} \mathrm{C}$ to $\mathrm{OD}_{600} \leq 0.2\left(\sim 3 \times 10^{8} \mathrm{cell} / \mathrm{sL}\right)$, inoculated to NAS agar medium, and incubated for two days at $28^{\circ} \mathrm{C}$. Single colonies that grew on NAS were then transferred to NA and NA containing kanamycin. Colonies that grew on NA, but not on $\mathrm{NA}^{\mathrm{Km}}$, were selected as potential deletion mutants. The mutants were then analyzed by Southern blot hybridization and PCR with primer pairs pKMSA1-5F/pKMSA1-3R and pKMSA2-5F/pKMSA2-3R (Table S1).

\section{Southern hybridizations}

Xcm plasmid and genomic DNA were extracted as described above. After BamHI digestion, DNA was separated on $1.2 \%$ agarose gels and then transferred onto Hybond $\mathrm{N}^{+}$nylon membranes (Roche, Germany). The 2898-bp internal Sphl fragment of pthXo1 (GenBank accession no: AY495676) from Xoo [84] was labeled with digoxigenin (DIG) and used as a hybridization probe to detect the tal genes. Probe labeling and Southern blotting were performed using the DIG Probe Synthesis Kit as recommended by the manufacturer's instructions (Roche, Sweden).

\section{Virulence assays}

Page $10 / 25$ 
Cotton cultivar TM-1 (G. hirsutum) was used in this study. Plants were grown in a greenhouse at $23^{\circ} \mathrm{C}$ with a 12-h light/dark photoperiod and $\sim 80 \% \mathrm{RH}$. Two-week-old plants were used in virulence assays. Single colonies of $X \mathrm{~cm}$ were inoculated to $4 \mathrm{~mL} \mathrm{NB}$ and cultured overnight at $28^{\circ} \mathrm{C}$. Bacterial cells were harvested by centrifugation (5000 rpm, $3 \mathrm{~min}$ ); pellets were washed twice in sterile $10 \mathrm{mM} \mathrm{MgCl}$ and then re-suspended in $10 \mathrm{mM} \mathrm{MgCl}_{2}$ buffer to $\mathrm{OD}_{600}=0.1\left(\sim 2 \times 10^{8}\right.$ cells $\left./ \mathrm{mL}\right)$. The suspensions were inoculated to the abaxial surface of leaves by infiltration with a sterile needleless syringe. Inoculation with simply $10 \mathrm{mM} \mathrm{MgCl}_{2}$ buffer served as a mock. Leaf phenotypes were examined 4-5 days after inoculation. Three independent plants were used, and the experiments were repeated three times with similar results. For the quantification of bacterial growth in cotton, triplicate leaf samples $\left(1 \mathrm{~cm}^{2}\right.$ in diameter) were collected for each inoculated strain and washed with $70 \%$ ethanol and double-distilled water (ddw). Samples were macerated in $1 \mathrm{~mL} d d w$ and incubated for 30 minutes at room temperature. Serial dilutions were then plated on NB agar medium with appropriate antibiotics for colony counts. The experiment was repeated three times, and the significant differences were determined by using student's $t$-test.

\section{Expression of tal2 gene in $\mathrm{Xcm} M 2$}

The plasmid pZWavrXa7 (supplied by Dr. Bing Yang) was used to construct the plasmid for expression of tal2 in Xss- $\mathrm{V}_{2}-18$ strain. Plasmid pZWavrXa7 contains a FLAG-tag epitope immediately downstream of the second $S p h l$ site in the C-terminus of AvrXa7. The central Sphl fragment of avrXa7 was replaced with the Sphl fragment of Xss- $\mathrm{V}_{2}-18$ tal2 gene to generate $\mathrm{pZW}$-tal2 (Table 1). The recombinant plasmid was then fused with broad-host-range vector pHM1 at the Hindlll site giving rise to $\mathrm{pHZW}$-tal2. The constructs were transformed into $X \mathrm{~cm}$ M2 ( $\Delta$ ta/2 strain, see below) by electroporation ( $2.5 \mathrm{kv}, 4 \mathrm{~ms})$.

The expression of ta/2 in M2 was confirmed by western blotting with flag-labelled antisera. Briefly, the M2 strain containing pHZW-tal2 was cultured in NB to the logarithmic phase and harvested by centrifugation. The pellets were washed twice, and re-suspended in $1 X$ PBS buffer to $\mathrm{OD}_{600}=1.0\left(\sim 3 \times 10^{9} \mathrm{cell} / \mathrm{sL}\right)$. SDS loading buffer (5X) was added to the bacterial suspensions and boiled in a water bath for $10 \mathrm{~min}$. Proteins were separated on $8 \%$ SDS-PAGE gels and transferred to polyvinylidene difluoride membranes for immunoblotting using anti-FLAG (TransGene, Beijing, China) as the primary antibody. Primary antibodies were detected using goat anti-mouse IgG $(H+L)$ (TransGen) and visualized with the EasySee Western Kit (TransGen). E. coli RNA polymerase subunit a (RNAP) was used as a loading control.

\section{Declaration}

\section{Authors' contributions}

GC contributed in conceiving and designing the experiments. $\mathrm{FH}$ and $\mathrm{HX}$ conducted the experiments and analyzed the data with assistance from SMAS, SW, WM, LC, XX, ZX, SW. LZ, and BZ. FH and GC wrote the paper; and all authors read, commented on, and approved the manuscript. 
Acknowledgments

We are thankful to Dr. Bing Yang, lowa State University, for providing pHZWavrXa7.

\section{Funding}

This research work was supported by the National Natural Science Foundation of China (grant numbers; 31830072, 31230059).

\section{Availability of data and materials}

All the dataset generated or analyzed during this study are included in this published article. The nucleotide sequences have been deposited in GenBank under the following accession numbers (MK654746-MK654751). The plasmids are available from the corresponding author on reasonable request.

\section{Ethics approval and consent to participate}

Not Applicable.

\section{Consent for publication}

Not Applicable.

\section{Competing interests}

The authors declare that they have no competing interests.

\section{References}

1. Sunilkumar G, Campbell LM, Puckhaber L, Stipanovic RD, Rathore KS. Engineering cottonseed for use in human nutrition by tissue-specific reduction of toxic gossypol. Proc Natl Acad Sci USA. 2006;103(48):18054-18059.

2. Sheth K. Top Cotton Producing Countries In The World. WorldAtlas. 2017. https://www.worldatlas.com/articles/top-cotton-producing-countries-in-the-world.html. Accessed 10 Dec, 2019.

3. Gotmare V, Singh P, Tule B. Wild and cultivated species of Cotton. In: Technical Bulletin; Central Institute for Cotton Research: Nagpur, India. 2000;5.

4. Li F, Fan G, Wang K, Sun F, Yuan Y, Song G, Li Q, Ma Z, Lu C, Zou C et al. Genome sequence of the cultivated cotton Gossypium arboreum. Nat Genet. 2014;46(6):567-572.

5. Holm F, Lindgren S. Impacts of Fairtrade on Small-Scale Cotton Producers-A field study in rural India. 2017. http://hdl.handle.net/2077/53773. Accessed 12 Dec, 2019. In. 
6. Atkinson GF. Black" rust" of Cotton. In. vol. 27: Agricultural Experiment Station of the Agricultural and Mechanical College; 1891.

7. Delannoy E, Lyon B, Marmey P, Jalloul A, Daniel J, Montillet J, Essenberg M, Nicole M. Resistance of cotton towards Xanthomonas campestris pv. malvacearum. Annu Rev Phytopathol. 2005;43:63-82.

8. Hillocks R. Bacterial blight. In: Cotton diseases. 1992: 39-85.

9. Al-Mousawi AH, Richardson P, Essenberg M, Johnson W. Ultrastructural Studies of a Compatible Interaction Between Xanthomonas campestris pv. malvacearum and Cotton. Phytopathology. 1982;72(9):1222-1230.

10. Büttner D, Bonas U. Regulation and secretion of Xanthomonas virulence factors. FEMS Microbiol Rev. 2010;34(2):107-133.

11. Pfeilmeier S, Caly DL, Malone JG. Bacterial pathogenesis of plants: future challenges from a microbial perspective: Challenges in Bacterial Molecular Plant Pathology. Mol Plant Pathol. 2016;17(8):1298-1313.

12. Melotto M, Kunkel BN. Virulence strategies of plant pathogenic bacteria. In: The Prokaryotes. Springer; 2013: 61-82.

13. Benali S, Mohamed B, Eddine HJ. Virulence strategies of phytopathogenic bacteria and their role in plant disease pathogenesis. Afr J Microbiol Res. 2014;8(30):2809-2815.

14. Xiao-bo X, Li-fang Z, Ma W-x, Zhi-yang L, Gong-you C. Identification of 17 HrpX-Regulated Proteins Including Two Novel Type III Effectors, XOC_3956 and XOC_1550, in Xanthomonas oryzae pv. oryzicola. PLoS One. 2014;9(3):e93205.

15. Guo W, Cai L-L, Zou H-S, Ma W-X, Liu X-L, Zou L-F, Li Y-R, Chen X-B, Chen G-Y. The ketoglutarate transport protein KgtP is secreted through the type III secretion system and contributes to virulence in Xanthomonas oryzae pv. oryzae. Appl Environ Microbiol. 2012:AEM. 07997-07911.

16. Furutani A, Takaoka M, Sanada H, Noguchi Y, Oku T, Tsuno K, Ochiai H, Tsuge S. Identification of novel type III secretion effectors in Xanthomonas oryzae pv. oryzae. Mol Plant-Microbe Interact. 2009;22(1):96-106.

17. Cui Y, Zou L, Zou H, Li Y, Zakria M, Chen G. HrpE3 is a type III effector protein required for full virulence of Xanthomonas oryzae pv. oryzicola in rice. Mol Plant Pathol. 2013;14(7):678-692.

18. Guo W, Cui Y-p, Li Y-r, Che Y-z, Yuan L, Zou L-f, Zou H-s, Chen G-y. Identification of seven Xanthomonas oryzae pv. oryzicola genes potentially involved in pathogenesis in rice. Microbiology. 2012;158(2):505-518.

19. Ji Z, Wang C, Zhao K. Rice Routes of Countering Xanthomonas oryzae. Int J Mol Sci. 2018;19(10):3008.

20. Shah SMA, Haq F, Ma W, Xu X, Wang S, Xu Z, Zou L, Zhu B, Chen G. Tal1 ${ }_{N X t c 01}$ in Xanthomonas translucens pv. cerealis Contributes to Virulence in Bacterial Leaf Streak of Wheat. Front Microbiol. 2019;10:2040. 
21. Cai L, Cao Y, Xu Z, Ma W, Zakria M, Zou L, Cheng Z, Chen G. A transcription activator-like effector Tal7 of Xanthomonas oryzae pv. oryzicola activates rice gene Os09g29100 to suppress rice immunity. Sci Rep. 2017;7(1):5089.

22. Ma W, Zou L, Ji Z, Xu X, Xu Z, Yang Y, Alfano JR, Chen G. Xanthomonas oryzae pv. oryzae TALE proteins recruit OsTFIIAY1 to compensate for the absence of OsTFIIAY5 in bacterial blight in rice. Mol Plant Pathol. 2018.

23. Ji Z-Y, Zakria M, Zou L-F, Xiong L, Li Z, Ji G-H, Chen G-Y. Genetic diversity of transcriptional activatorlike effector genes in Chinese isolates of Xanthomonas oryzae pv. oryzicola. Phytopathology. 2014;104(7):672-682.

24. Peng Z. Contribution of TAL effectors in Xanthomonas to diseases of rice and wheat. Kansas State University; 2015.

25. Yang $Y$, Yuan Q, Gabriel DW. Watersoaking function (s) of $\mathrm{XcmH} 1005$ are redundantly encoded by members of the Xanthomonas avr/ pth gene family. Mol Plant-Microbe Interact. 1996;9(2):105-113.

26. Chakrabarty P, Duan Y, Gabriel D. Cloning and characterization of a member of the Xanthomonas avr/ pth gene family that evades all commercially utilized cotton $\mathrm{R}$ genes in the United States. Phytopathology. 1997;87(11):1160-1167.

27. Cox KL, Meng F, Wilkins KE, Li F, Wang P, Booher NJ, Carpenter SC, Chen L-Q, Zheng H, Gao X. TAL effector driven induction of a SWEET gene confers susceptibility to bacterial blight of cotton. Nat Commun. 2017;8:15588.

28. Feyter RD, Gabriel DW. At-least six avirulence genes are clustered on a 90-kilobase plasmid in Xanthomonas campestris pv. malvacearum. Mol Plant-Microbe Interact. 1991;4(5):423-432.

29. Römer P, Hahn S, Jordan T, Strauß T, Bonas U, Lahaye T. Plant pathogen recognition mediated by promoter activation of the pepper Bs3 resistance gene. Science. 2007;318(5850):645-648.

30. Boch J, Bonas U. Xanthomonas AvrBs3 family-type III effectors: discovery and function. Annu Rev Phytopathol. 2010;48:419-436.

31. Boch J, Scholze H, Schornack S, Landgraf A, Hahn S, Kay S, Lahaye T, Nickstadt A, Bonas U. Breaking the code of DNA binding specificity of TAL-type III effectors. Science. 2009;326(5959):15091512.

32. Deng D, Yan C, Pan X, Mahfouz M, Wang J, Zhu J-K, Shi Y, Yan N. Structural basis for sequencespecific recognition of DNA by TAL effectors. Science. 2012;335(6069):720-723.

33. Yang B, Sugio A, White FF. Os8N3 is a host disease-susceptibility gene for bacterial blight of rice. Proc Natl Acad Sci USA. 2006;103(27):10503-10508.

34. Zhou J, Peng Z, Long J, Sosso D, Liu B, Eom J-S, Huang S, Liu S, Vera Cruz C, Frommer WB et al. Gene targeting by the TAL effector PthXo2 reveals cryptic resistance gene for bacterial blight of rice. Plant J. 2015;82(4):632-643.

35. Yuan M, Chu Z, Li X, Xu C, Wang S. Pathogen-induced expressional loss of function is the key factor in race-specific bacterial resistance conferred by a recessive $\mathrm{R}$ gene xa13 in rice. Plant Cell Physiol. 2009;50(5):947-955. 
36. Chu Z, Yuan M, Yao J, Ge X, Yuan B, Xu C, Li X, Fu B, Li Z, Bennetzen JL et al. Promoter mutations of an essential gene for pollen development result in disease resistance in rice. Genes Dev. 2006;20(10):1250-1255.

37. Liu Q, Yuan M, Zhou Y, Li X, Xiao J, Wang S. A paralog of the MtN3/saliva family recessively confers race-specific resistance to Xanthomonas oryzae in rice. Plant, Cell Environ. 2011;34(11):1958-1969.

38. Tran TT, Perez-Quintero AL, Wonni I, Carpenter SC, Yu Y, Wang L, Leach JE, Verdier V, Cunnac S, Bogdanove AJ et al. Functional analysis of African Xanthomonas oryzae pv. oryzae TALomes reveals a new susceptibility gene in bacterial leaf blight of rice. PLoS Path. 2018;14(6):e1007092.

39. Gu K, Yang B, Tian D, Wu L, Wang D, Sreekala C, Yang F, Chu Z, Wang G-L, White FF et al. R gene expression induced by a type-Ill effector triggers disease resistance in rice. Nature. 2005;435(7045):1122.

40. Tian D, Wang J, Zeng X, Gu K, Qiu C, Yang X, Zhou Z, Goh M, Luo Y, Murata-Hori M et al. The rice TAL effector-dependent resistance protein XA10 triggers cell death and calcium depletion in the endoplasmic reticulum. The Plant Cell. 2014:tpc. 113.119255.

41. Wang C, Zhang X, Fan Y, Gao Y, Zhu Q, Zheng C, Qin T, Li Y, Che J, Zhang M et al. XA23 is an executor $\mathrm{R}$ protein and confers broad-spectrum disease resistance in rice. Molecular plant. 2015;8(2):290-302.

42. Ji Z, Ji C, Liu B, Zou L, Chen G, Yang B. Interfering TAL effectors of Xanthomonas oryzae neutralize R-gene-mediated plant disease resistance. Nat Commun. 2016;7:13435.

43. Read AC, Rinaldi FC, Hutin M, He Y-Q, Triplett LR, Bogdanove AJ. Suppression of Xo1-mediated disease resistance in rice by a truncated, non-DNA-binding TAL effector of Xanthomonas oryzae. Front Plant Sci. 2016;7:1516.

44. Knight R, Clouston T. The genetics of blackarm resistance. J Genet. 1939;38(1-2):133-159.

45. Baldwin Jr C. Report of the Bacterial Blight Committee-1975 [Cotton, USA]. In: Proceedings Beltwide Cotton Production Research Conferences: 1976.

46. Phillips AZ, Berry JC, Wilson MC, Vijayaraghavan A, Burke J, Bunn JI, Allen TW, Wheeler T, Bart RS. Genomics-enabled analysis of the emergent disease cotton bacterial blight. PLoS Genet. 2017;13(9):e1007003.

47. Gabriel DW, Burges A, Lazo GR. Gene-for-gene interactions of five cloned avirulence genes from Xanthomonas campestris pv. malvacearum with specific resistance genes in cotton. Proc Natl Acad Sci USA. 1986;83(17):6415-6419.

48. Yang Y. Host-specific symptoms and increassed release of Xanthomonas citri and $X$. campestris pv. malvacearum from leaves are determined by the 102-bp tandem repeats of pthA and avrb6, respectively. Mol Plant-Microbe Interact. 1994;7:345-355.

49. Booher NJ, Carpenter SC, Sebra RP, Wang L, Salzberg SL, Leach JE, Bogdanove AJ. Single molecule real-time sequencing of Xanthomonas oryzae genomes reveals a dynamic structure and complex TAL (transcription activator-like) effector gene relationships. Microbial genomics. 2015;1(4).

50. Grau J, Reschke M, Erkes A, Streubel J, Morgan RD, Wilson GG, Koebnik R, Boch J. AnnoTALE: bioinformatics tools for identification, annotation, and nomenclature of TALEs from Xanthomonas 
genomic sequences. Sci Rep. 2016;6:21077.

51. Salzberg SL, Sommer DD, Schatz MC, Phillippy AM, Rabinowicz PD, Tsuge S, Furutani A, Ochiai H, Delcher AL, Kelley D et al. Genome sequence and rapid evolution of the rice pathogen Xanthomonas oryzae pv. oryzae PX099 A. BMC Genomics. 2008;9(1):204.

52. Quibod IL, Perez-Quintero A, Booher NJ, Dossa GS, Grande G, Szurek B, Cruz CV, Bogdanove AJ, Oliva R. Effector diversification contributes to Xanthomonas oryzae pv. oryzae phenotypic adaptation in a semi-isolated environment. Sci Rep. 2016;6:34137.

53. Gonzalez C, Szurek B, Manceau C, Mathieu T, Séré Y, Verdier V. Molecular and pathotypic characterization of new Xanthomonas oryzae strains from West Africa. Mol Plant-Microbe Interact. 2007;20(5):534-546.

54. Bogdanove AJ, Koebnik R, Lu H, Furutani A, Angiuoli SV, Patil PB, Van Sluys M-A, Ryan RP, Meyer DF, Han S-W. Two new complete genome sequences offer insight into host and tissue specificity of plant pathogenic Xanthomonas spp. J Bacteriol. 2011:JB. 05262-05211.

55. Wilkins KE, Booher NJ, Wang L, Bogdanove AJ. TAL effectors and activation of predicted host targets distinguish Asian from African strains of the rice pathogen Xanthomonas oryzae pv. oryzicola while strict conservation suggests universal importance of five TAL effectors. Front Plant Sci. 2015;6:536.

56. Khojasteh M, Shah SMA, Haq F, Xu X, Taghavi SM, Osdaghi E, Chen G. Transcription Activator-Like Effectors Diversity in Iranian Strains of Xanthomonas translucens. Phytopathology ${ }^{\mathrm{TM}} .0(0)$ :PHYTO-1119-0428-R.

57. Falahi Charkhabi N, Booher NJ, Peng Z, Wang L, Rahimian H, Shams-Bakhsh M, Liu Z, Liu S, White $\mathrm{FF}$, Bogdanove AJ. Complete genome sequencing and targeted mutagenesis reveal virulence contributions of Tal2 and Tal4b of Xanthomonas translucens pv. undulosa ICMP11055 in bacterial leaf streak of wheat. Front Microbiol. 2017;8:1488.

58. Peng Z, Hu Y, Xie J, Potnis N, Akhunova A, Jones J, Liu Z, White FF, Liu S. Long read and single molecule DNA sequencing simplifies genome assembly and TAL effector gene analysis of Xanthomonas translucens. BMC Genomics. 2016;17(1):21.

59. Showmaker KC, Arick MA, Hsu C-Y, Martin BE, Wang X, Jia J, Wubben MJ, Nichols RL, Allen TW, Peterson DG. The genome of the cotton bacterial blight pathogen Xanthomonas citri pv. malvacearum strain MSCT1. Stand Genomic Sci. 2017;12(1):42.

60. Zou L-F, Li Y-R, Chen G-Y. A non-marker mutagenesis strategy to generate poly-hrp gene mutants in the rice pathogen Xanthomonas oryzae pv. oryzicola. Agr Sci China. 2011;10(8):1139-1150.

61. Blank LM, Bird LS. Breeding Strains of Cotton Resistant to Bacterial Blight. Texas FARMER Collection. 1951.

62. Green JM, Brinkerhoff L. Inheritance of Three Genes for Bacterial Blight Resistance in Upland Cotton 1. Agron J. 1956;48(11):481-485.

63. Simpson D, Weindling R. Bacterial blight resistance in a strain of Stoneville cotton. Agron J. 1946;38(7):630-635. 
64. Scholze H, Boch J. TAL effectors are remote controls for gene activation. Curr Opin Microbiol. 2011;14(1):47-53.

65. El Yacoubi B, Brunings A, Yuan Q, Shankar S, Gabriel D. In planta horizontal transfer of a major pathogenicity effector gene. Appl Environ Microbiol. 2007;73(5):1612-1621.

66. Alegria MC, Souza DP, Andrade MO, Docena C, Khater L, Ramos CH, Da Silva AC, Farah CS. Identification of new protein-protein interactions involving the products of the chromosome-and plasmid-encoded type IV secretion loci of the phytopathogen Xanthomonas axonopodis pv. citri. J Bacteriol. 2005;187(7):2315-2325.

67. Shybut ME. Transcription Activator-Like (TAL) Effectors of the Cassava Bacterial Blight Pathogen Xanthomonas axonopodis pv. manihotis: University of California, Berkeley; 2015.

68. Pesce C, Bolot S, Cunnac S, Portier P, Fischer-Le Saux M, Jacques MA, Gagnevin L, Arlat M, Noël LD, Carrère $S$ et al. High-Quality Draft Genome Sequence of the Xanthomonas translucens pv. cerealis Pathotype Strain CFBP 2541. Genome Announc. 2015;3(1).

69. Xu Z, Xu X, Gong Q, Li Z, Li Y, Wang S, Yang Y, Ma W, Liu L, Zhu B. Engineering broad-spectrum bacterial blight resistance by simultaneously disrupting variable TALE-binding elements of multiple susceptibility genes in rice. Molecular plant. 2019;12(11):1434-1446.

70. Pérez-Quintero AL, Lamy L, Gordon J, Escalon A, Cunnac S, Szurek B, Gagnevin L. QueTAL: a suite of tools to classify and compare TAL effectors functionally and phylogenetically. Front Plant Sci. 2015;6:545.

71. Chen NW, Serres-Giardi L, Ruh M, Briand M, Bonneau S, Darrasse A, Barbe V, Gagnevin L, Koebnik R, Jacques M-A. Horizontal gene transfer plays a major role in the pathological convergence of Xanthomonas lineages on common bean. BMC Genomics. 2018;19(1):606.

72. Ruh M, Briand M, Bonneau S, Jacques M-A, Chen NW. Xanthomonas adaptation to common bean is associated with horizontal transfers of genes encoding TAL effectors. BMC Genomics. 2017;18(1):670.

73. Jiang J, Zou H, Li Y, Chen G. Expression of the hrcC, hrpE and hpa3 genes is not regulated by the hrpG and hrpX genes in a rice pathogen Xanthomonas oryzae pv. oryzicola. Acta Microbiol Sin. 2009;49(8):1018-1025.

74. Wang Y, Zou L, Zhou D, Chen G. Key roles of hrpE gene of Xanthomonas oryzae pv. oryzicola in formation of Hrp pilus and pathogenicity in rice. Acta Phytopathol Sin. 2009;39(4):392-398.

75. Yanfei C, Lifang Z, Wenxiang Z, Zhiyuan J, Huasong Z, Gongyou C. Establishment of avrBs3/pthA Family Gene Knockout System of Rice Leaf Spot Pathogen. J Zhejiang Univ (Agric Life Sci). 2011;37(1):40-48.

76. Antony G, Zhou J, Huang S, Li T, Liu B, White F, Yang B. Rice xa13 recessive resistance to bacterial blight is defeated by induction of the disease susceptibility gene Os-11N3. The plant cell. 2010;22:3864-3876.

77. Cernadas RA, Doyle EL, Niño-Liu DO, Wilkins KE, Bancroft T, Wang L, Schmidt CL, Caldo R, Yang B, White FF et al. Code-assisted discovery of TAL effector targets in bacterial leaf streak of rice reveals 
contrast with bacterial blight and a novel susceptibility gene. PLoS Path. 2014;10(2):e1003972.

78. Cohn M, Bart RS, Shybut M, Dahlbeck D, Gomez M, Morbitzer R, Hou B-H, Frommer WB, Lahaye T, Staskawicz BJ. Xanthomonas axonopodis virulence is promoted by a transcription activator-like effector-mediated induction of a SWEET sugar transporter in cassava. Mol Plant-Microbe Interact. 2014;27(11):1186-1198.

79. Hu Y, Zhang J, Jia H, Sosso D, Li T, Frommer WB, Yang B, White FF, Wang N, Jones JB. Lateral organ boundaries 1 is a disease susceptibility gene for citrus bacterial canker disease. Proc Natl Acad Sci USA. 2014;111(4):E521-E529.

80. Peng Z, Hu Y, Zhang J, Huguet-Tapia JC, Block AK, Park S, Sapkota S, Liu Z, Liu S, White FF. Xanthomonas trans/ucens commandeers the host rate-limiting step in ABA biosynthesis for disease susceptibility. Proc Natl Acad Sci USA. 2019;116(42):20938-20946.

81. Wu D, von Roepenack-Lahaye E, Buntru M, de Lange O, Schandry N, Pérez-Quintero AL, Weinberg Z, Lowe-Power TM, Szurek B, Michael AJ. A plant pathogen type III effector protein subverts translational regulation to boost host polyamine levels. Cell Host \& Microbe. 2019;26(5):638-649. e635.

82. Tran TT, Doucouré H, Hutin M, Niño LJ, Szurek B, Cunnac S, Koebnik R. Efficient enrichment cloning of TAL effector genes from Xanthomonas. MethodsX. 2018;5:1027-1032.

83. Erkes A, Reschke M, Boch J, Grau J. Evolution of transcription activator-like effectors in Xanthomonas oryzae. GENOME BIOL EVOL. 2017;9(6):1599-1615.

84. Yang B, White FF. Diverse members of the AvrBs3/PthA family of type III effectors are major virulence determinants in bacterial blight disease of rice. Mol Plant-Microbe Interact. 2004;17(11):1192-1200.

85. Hopkins CM, White F, Choi S, Guo A, Leach J. Identification of a family of avirulence genes from Xanthomonas oryzae pv. oryzae. Mol Plant Microbe Interact. 1992;5(6):451-459.

86. Yang B, Zhu W, Johnson LB, White FF. The virulence factor AvrXa7 of Xanthomonas oryzae pv. oryzae is a type III secretion pathway-dependent nuclear-localized double-stranded DNA-binding protein. Proc Natl Acad Sci USA. 2000;97(17):9807-9812.

\section{Table}

Table 1. List of strains and plasmids used in this study 


\begin{tabular}{|c|c|c|}
\hline $\begin{array}{l}\text { Strain or } \\
\text { plasmid }\end{array}$ & Relevant characteristics & Source \\
\hline \multicolumn{3}{|c|}{ Escherichia coli } \\
\hline DH5 $\alpha$ & $\begin{array}{l}F^{2} \varphi 80 \text { lacZAM15 (lacZYA-argF)U169 deoR recA1 endA1 } \\
\text { hsdR17(rk-, mk+) phoA supE44 } \lambda \text { - thi-1 gyrA96 relA1 }\end{array}$ & Clontech \\
\hline \multicolumn{3}{|c|}{ X. citri pv. malvacearum } \\
\hline MSCT1 & Wild-type, causes bacterial blight of cotton & [59] \\
\hline XcmH1005 & Spontaneous Rif $^{\mathrm{r}}$ derivative of $\mathrm{XcmN}$ & {$[27]$} \\
\hline XcmH1003 & $\mathrm{Sp}^{\mathrm{r}}, \mathrm{Rif}^{\mathrm{r}}$ derivative of $\mathrm{XcmN}$ & {$[27]$} \\
\hline Xcc049 & Wild-type $X C C$ strain, used for construction of pKMSA1/A2 & This lab \\
\hline $\mathrm{Xss}-\mathrm{V}_{2}-18$ & Wild-type, causes bacterial blight of cotton & $\begin{array}{l}\text { Hainan } \\
\text { University, } \\
\text { China }\end{array}$ \\
\hline M1 & tal3 deletion mutant of $\mathrm{Xss}-\mathrm{V}_{2}-18$ & This study \\
\hline M2 & tal2 deletion mutant of $\mathrm{Xss}-\mathrm{V}_{2}-18$ & This study \\
\hline M3 & tal2 tal4 deletion mutant of $\mathrm{Xss}-\mathrm{V}_{2}-18$ & This study \\
\hline M4 & tal2 tal4 tal5 tal6 deletion mutant of $\mathrm{Xss} \mathrm{V}_{2}-18$ & This study \\
\hline M5 & tal2 tal3 tal4 tal5 tal6 deletion mutant of Xss-V $\mathrm{V}_{2}-18$ & This study \\
\hline M6 & tal-free mutant of $\mathrm{Xss}-\mathrm{V}_{2}-18$ & This study \\
\hline \multicolumn{3}{|l|}{ Plasmids } \\
\hline $\begin{array}{l}\text { pBluescript } \\
\text { II SK(-) }\end{array}$ & $\mathrm{Ap}^{\mathrm{r}}$, phagemid, $\mathrm{pUC}$ derivative & $\begin{array}{l}\text { Lab } \\
\text { collection }\end{array}$ \\
\hline pMD18-T & $\mathrm{Ap}^{\mathrm{r}}, \mathrm{pUC18}$ derivative, TA cloning vector, $2692 \mathrm{bp}$ & TaKaRa \\
\hline pKMS1 & $\mathrm{Km}^{\mathrm{r}}$, sacB mob lacZ oriV, 6475 bp & {$[60]$} \\
\hline pHM1 & Broad-spectrum cosmid vector, cos, parA, IncW, $\mathrm{Sp}^{\mathrm{r}}$ & {$[85]$} \\
\hline pKMSA1 & $\begin{array}{l}\text { pKMS1 containing a 930-bp XbaI/ SmaI fragment; insert } \\
\text { contains a fusion of a and } b \text { fragments that encode the } \mathrm{N} \text { - and } \\
\text { C-terminal sides of the tal CRR; } \mathrm{Km}^{\mathrm{r}}\end{array}$ & This study \\
\hline pKMSA2 & $\begin{array}{l}\text { pKMS1 containing a } 450-\mathrm{bp} X b a I / \text { SmaI fragment; insert } \\
\text { contains a fusion of the } c \text { and } d \text { fragments that encode the } \mathrm{N} \text { - } \\
\text { and C-terminal sides of the tal CRR; } \mathrm{Km}^{\mathrm{r}}\end{array}$ & This study \\
\hline pB-tal1 & pBluescript $₫ \mathrm{SK}(-)$ containing tal1 of Xss-V $\mathrm{V}_{2}-18$ & This study \\
\hline pB-tal2 & pBluescript II SK(-) containing tal2 of Xss- $\mathrm{V}_{2}-18$ & This study \\
\hline pB-tal3 & pBluescript II SK(-) containing tal3 of Xss- $\mathrm{V}_{2}-18$ & This study \\
\hline pB-tal4 & pBluescript II SK(-) containing tal4 of Xss-V $\mathrm{V}_{2}-18$ & This study \\
\hline
\end{tabular}




\begin{tabular}{|c|c|c|}
\hline pB-tal5 & pBluescript II SK(-) containing tal5 of Xss-V $\mathrm{V}_{2}-18$ & This study \\
\hline pB-tal6 & pBluescript II SK(-) containing tal6 of Xss-V $\mathrm{V}_{2}-18$ & This study \\
\hline pZWavrXa7 & $\begin{array}{l}\text { avrXa7 in pBluescript II KS+, contains FLAG epitope } \\
\text { immediately downstream of the second SphI site in the C- } \\
\text { terminus of AvrXa7, } \mathrm{Ap}^{\mathrm{r}}\end{array}$ & [86] \\
\hline pZW-tal2 & SphI fragment of tal2 in pZWavrXa7, $\mathrm{Ap}^{\mathrm{r}}$ & This study \\
\hline pHZW-tal2 & $\begin{array}{l}\text { pHM1 fused with pZW-tal2 at HindIII, lacZ promoter upstream } \\
\text { of tal2, } \mathrm{Ap}^{\mathrm{r}}, \mathrm{Sp}^{\mathrm{r}}\end{array}$ & This study \\
\hline
\end{tabular}

\section{Figures}

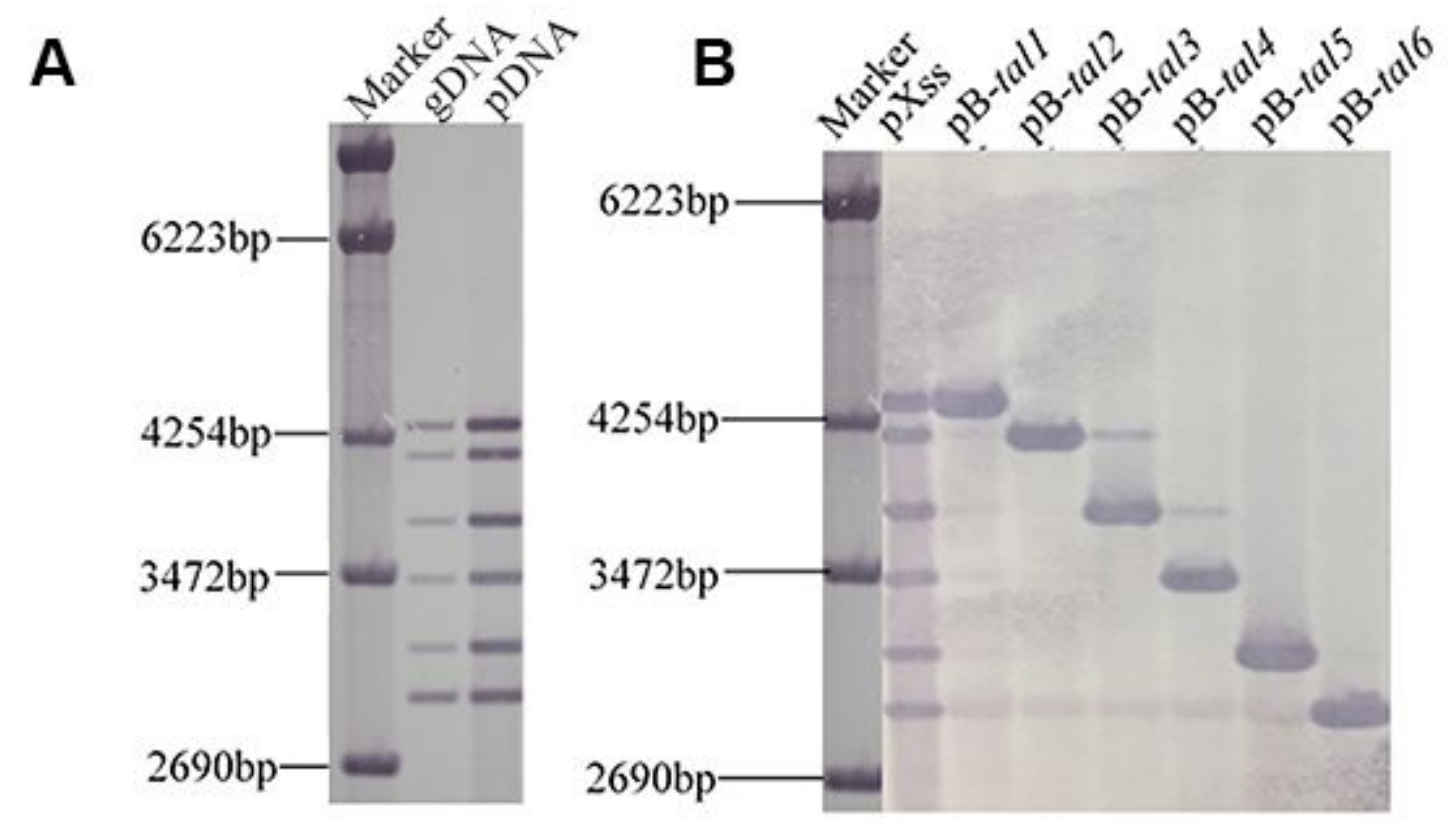

C

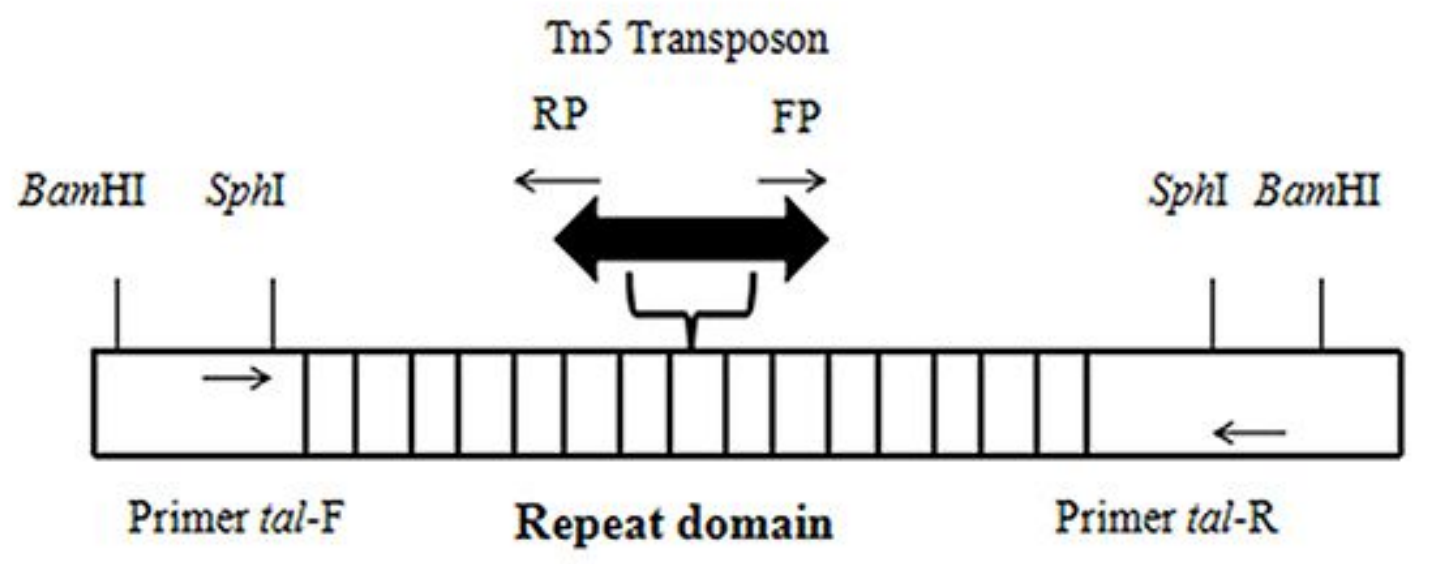

Figure 1 
Southern blotting, and Isolation and sequencing of Xss-V2-18 tal-genes. (A) Southern blot analysis of BamHI-digested genomic (gDNA) and plasmid DNA (pDNA) of Xcm strain Xss-V2-18. A 2.9-kb Sphl fragment of pthXo1 (from Xoo) was labeled with digoxygenin (DIG) and used as a probe to detect tal genes in Xcm Xss-V2-18. (B) Plasmid DNA of Xss-V2-18 was digested with BamHI, and fragments were gel-purified and ligated into BamHI-digested and CIP-treated pBluescript II SK(-). Southern blot analysis was performed by the using internal Sphl fragment of pthXo1 as a probe to confirm each clone (pB-tal1 pB-tal6). (C) Schematic diagram of strategy used to sequence tal genes. After cloning into pBluescript II SK(-), the EZ-Tn5TM<KAN-2>Tnp TransposomeTM Kit was used to insert Tn5 into each tal gene. Clones with Tn5 insertions in the middle of the CRR were selected by Sphl digestion and sequenced using primer pairs tal-F/RP and FP/tal-R. 

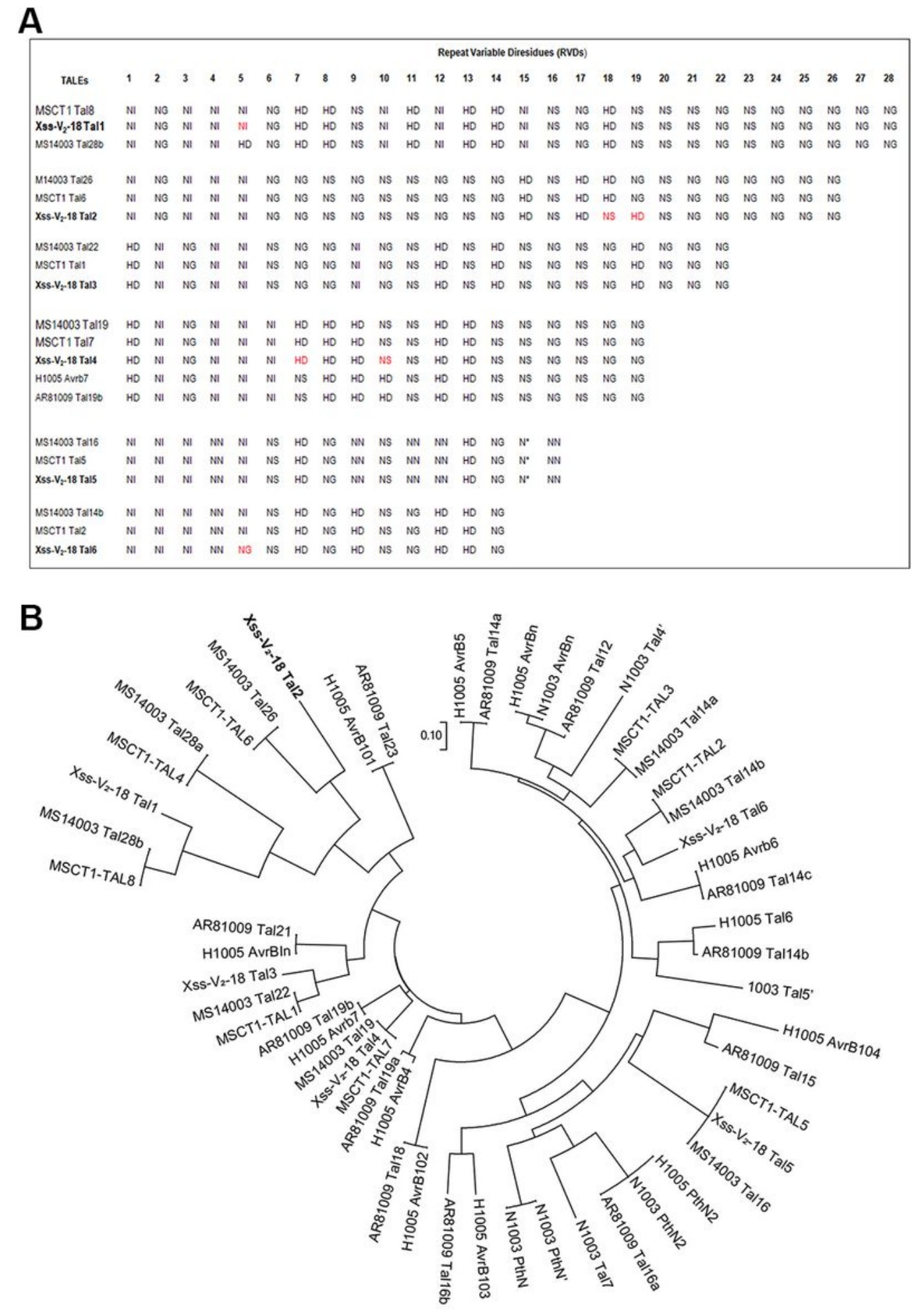

Figure 2

TALEs Phylogeny and Alignment of TALE RVDs. (A) Alignment of TALE RVDs from Xcm strains Xss-V218, MSCT1, H1005, MS14003 and AR81009 with AnnoTALE (version 1.4.1). Letters in red font indicate RVDs that differ between the two strains. The asterisk represents a missing amino acid residue (B) Construction of phylogenetic tree based on central repeat amino acid sequences of TALEs. A set of 53 TAL effector sequences from 6 different Xcm strains were used to construct tree with DisTAL program 
using default parameters. TALEs were classified into 6 major groups and 33 sub-groups showing the relationship of Xcm Xss-V2-18 to other Xcm strains published previously. Tal2 of Xss-V2-18, TAL6 of MCST and Tal26 (M26) of MS14003 fall in same group. Scale is shown below the tree.
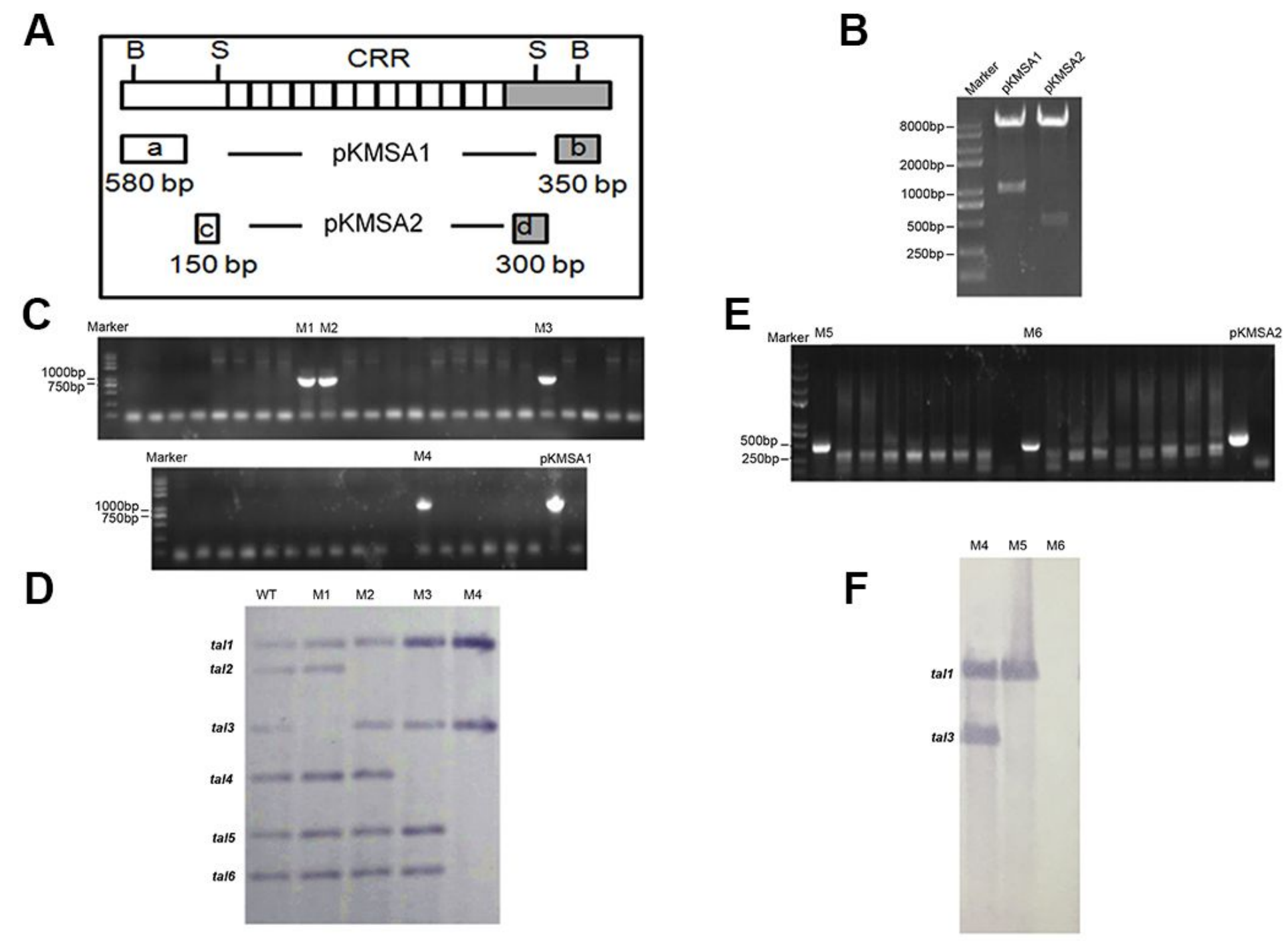

Figure 3

Deletion mutagenesis of Xss-V2-18 tal genes. (A) Schematic diagram of suicide plasmids pKMSA1 and pKMSA2. Fragments a (580 bp) and b (350 bp) were amplified on the left and right sides of the CRR, respectively, and cloned as a fused fragment in pKMSA1. Fragments c (580 bp) and d (150 bp) were amplified on the left and right sides of the CRR, respectively, and cloned as a fused fragment in pKMSA2. Constructs pKMSA1 and pKMSA2 were introduced into Xcm strain Xss- V2-18 by electroporation, and deletion of the CRR region was conducted as described in Methods. (B) Confirmation of 930- and 450- bp inserts in pKMSA1 and pKMSA2, respectively, by digestion with Xbal and Smal. (C) PCR analysis of 41 putative mutants with primers pKMSA1-5F and pKMSA1-3R. A 930-bp fragment was amplified in M1, M2, $M 3$, and $M 4$, indicating that these four mutants underwent a homologous recombination and potential deletion of the CRR region. pKMSA1 was included as a control. (D) Southern hybridization analysis of Xss-V2-18 and mutant strains M1-M4. Plasmid DNA of WT Xss-V2-18 and mutants were isolated and 
digested with BamHI. The internal Sphl fragment of pthXo1 (from Xoo) was used as a hybridization probe to detect tal genes. (E) PCR screening for putative mutants using primers pKMSA2-5F and pKMSA2-3R. pKMSA2 was included and used as a positive control. (F) Southern hybridization analysis of mutant M4 (used for second round of mutagenesis), M5 and M6. Plasmid DNA of M4, M5 and M6 were isolated and digested with BamHI, and the internal Sphl fragment of pthXo1 was used a hybridization probe to detect tal genes.
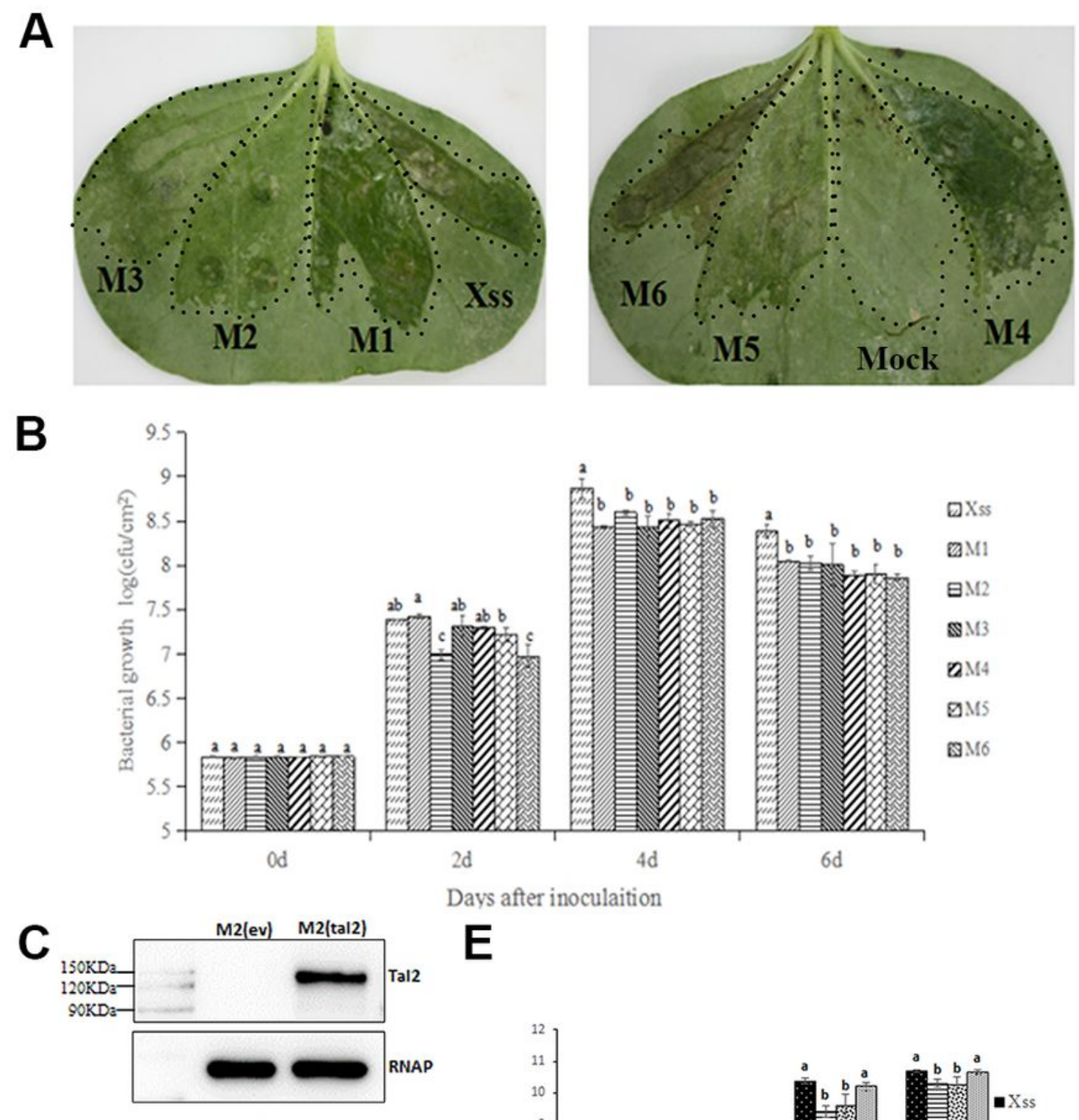

E
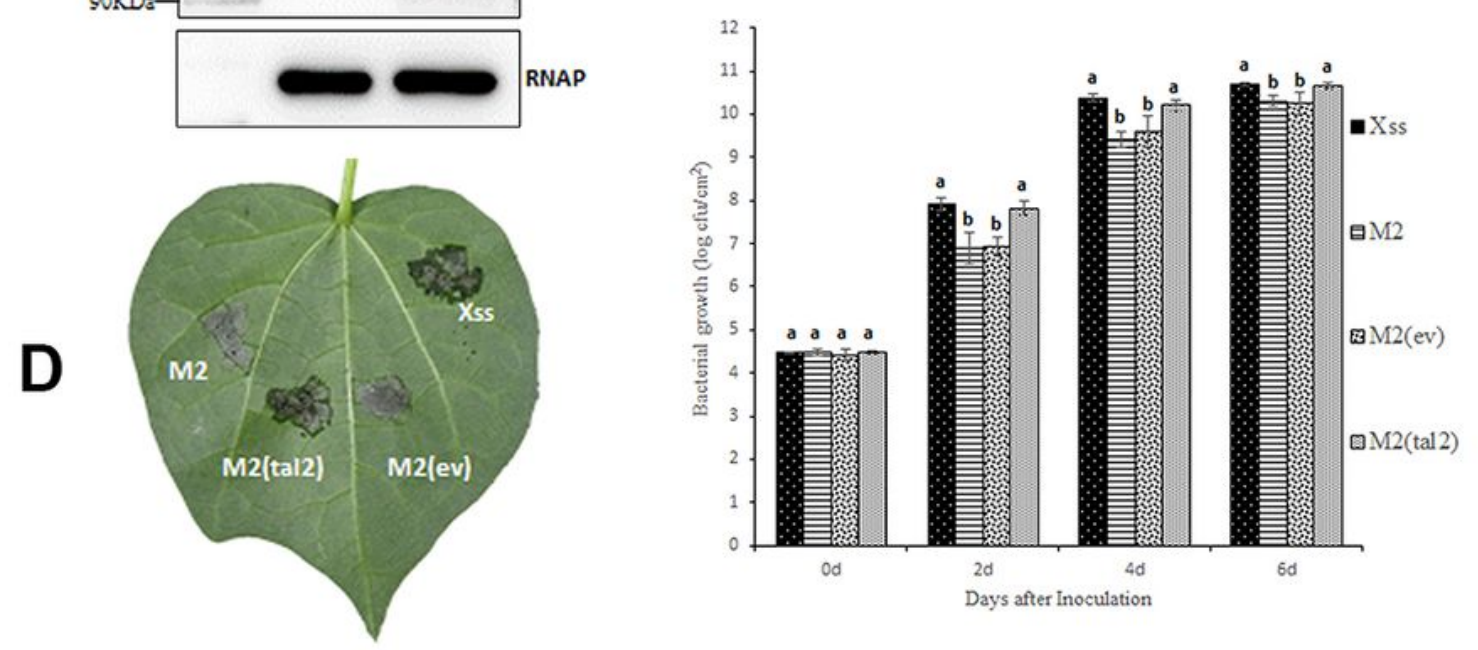

Figure 4 
Tal2 contribution to virulence of Xss-V2-18 on cotton variety TM-1. (A) Phenotypes of the mutant strains relative to wild-type Xss-V2-18. Wild-type (WT) and mutant strains were inoculated to the lower surface of cotton leaves (two-week-old plants) using a needleless syringe. Infiltration with simply $10 \mathrm{mM} \mathrm{MgCl} 2$ served as a mock. Phenotypes were observed 3-5 days post-inoculation. (B) In planta growth of WT XssV2-18 and mutants. Growth was measured at 0, 2, 4, and 6 days post-inoculation. Error bars represent means and standard deviations (means $\pm S D$ ), and columns labeled with different letters represent significant differences $(P<0.05)$. (C) Western blot analysis of TALE production in $\mathrm{Xcm} M 2$. Plasmid pHZW-tal2 was transferred into Xcm M2 by electroporation. Production of TALE was analyzed by western blotting using an anti-FLAG primary antibody (see Methods). RNA polymerase subunit alpha (RNAP) from E. coli, was used as a loading control. (D) Symptoms in cotton leaves inoculated with Xss-V2-18, mutant $M 2, M 2$ containing empty vector and M2 containing tal2 in trans. Bacterial strains were inoculated to cotton leaves using a needleless syringe, and phenotypes were observed within 5-7 days post-inoculation. (E) In planta growth of the WT Xss-V2-18, mutant M2 and complemented strain. Growth was measured at $0,2,4$, and 6 days post-inoculation. Error bars represent means and standard deviations (means $\pm S D$ ), and columns labeled with different letters represent significant differences $(P<0.05)$.

\section{Supplementary Files}

This is a list of supplementary files associated with this preprint. Click to download.

- SupplementaryMaterial.docx 